\title{
IMPLEMENTATION OF THE SUSTAINABLE DEVELOPMENT CONCEPT IN MANUFACTURING COMPANIES
}

\author{
Joanna, TABOR \\ Czestochowa University of Technology, Poland, joanna.tabor@interia.pl
}

\begin{abstract}
The sustainable development concept has become an extraordinarily important formative element of all activities taken by both law makers and the society, including entrepreneurs, for favour of broadly comprehended natural environment protection. This article presents the analysis of practical implementation of the sustainable development concept in manufacturing companies in Poland in the years 2010-2012. It also verifies directions of expenditures made towards environmental protection fixed assets, depending upon investment types, i.e. whether they were end-of-pipe investments or integrated technology investments. It was found that in the industrial processing sector in Poland, the highest average share of expenditures was associated with air and water protection fixed assets, whereas, in case of amounts spent on air protection means, a fall was observed in their share, and an increase in case of water protection. Furthermore, end-of-pipe investments dominated within the structure, whereas an increase was observed in the share end-of-pipe investments, and a fall in the share of integrated technology investments. It was also found that total amounts spent on environmental protection fixed assets per one company and per one employee increased, and the share of this type of expenditures in the total value of fixed assets obtained from manufacturing companies' investment activities increased as well.

KEY WORDS: sustainable development, "end of pipe", integrated technologies, manufacturing companies
\end{abstract}

\section{INTRODUCTION}

Today, the necessity to secure natural environment both for the present and future generations has become a pre-dominating paradigm and at the same time the most significant challenge that shapes the global economic policy and influences modern businesses' developmental directions. This policy manifests itself in the sustainable development concept which is reflected in plentiful legal acts, both at the international and the local level. Sustainable development is such a social and economic development, in which there occurs a process of integration of political, economic and social activities, with natural equilibrium and durability of basic natural processes being maintained in order to warrant the possibility to satisfy basic needs of particular communities or citizens of both the present and future generations [14].

Hence, with reference to companies, it means running businesses in such a way as to preserve the balance between economic, human and natural assets. Therefore, sustainable development in a company primarily means the need to account for ecological conditions while setting its developmental directions, not exceeding ecologically justified limits of allowable standards, and adapting its developmental requirements to regional and local conditions [1].

In practice, this translates into performance actions that are socially responsible, ecologically friendly and economically valuable [6], and which may comprise such activities as: using waste treatment facilities, utilising hazardous waste, using no waste or little waste generating technologies, using less harmful resources and materials, waste recovery and re-use, using energy-saving facilities, supporting charity campaigns and community projects, and using the code of ethics in contacts with employees, contracting parties and consumers.

\section{IMPLEMENTATION \\ OF THE SUSTAINABLE DEVELOPMENT CONCEPT WITH REFERENCE TO THE ENVIRONMENT AND THE MANUFACTURING PROCESSES}

Implementation of the sustainable development concept with reference to the environment manifests itself in accounting for ecological issues in company management strategies, which takes place through a number of actions such as [7]:

- implementing environmentally friendly innovations, i.e.: changes in manufacturing techniques and technologies to reduce negative impacts of manufacturing processes upon the environment;

- enforcing cleaner production projects - i.e. keeping improving features of products and manufacturing processes over the whole of their life cycles in order to reduce consumption levels of raw materials and volumes and toxicity levels of waste, as well as other natural and social environment hazards;

- $\quad$ implementing quality assurance systems and total quality management systems TQM; and

- $\quad$ implementing environmental policies, programs and using environmental management systems.

One of the EU's most important legal acts concerning environmental protection is Directive 96/61/EC upon Integrated Pollution Prevention and Control (as amended in 2008 2008/1/EC), called the IPPC Directive. This Directive contains 
some provisions concerning environmental impacts and control of manufacturing processes in order to reduce pollution emissions using state-of-the-art technologies codified as guidelines for BATs (Best Available Techniques). The objective of the BAT standard introduction was to propose such emission limits which would reflect desirable proportions between environmental costs and benefits. Unfortunately, the standard fails to define the facility type or a specific technology. Based upon BATs, emission limits have been set, which must take into account both the installation's engineering characteristics and its geographical location and its local environmental conditions. The best available BAT techniques [14] have been defined as the most effective and advanced development level of technologies and methods to run a given business, and used as a basis to set threshold emission values aimed at eliminating emissions, or, in case this is not possible in practice, at limiting these emissions and impacts upon the environment as a whole, whereas the concepts of:

a) "technique" means both the technology used and the way a given installation is to be designed, built, operated, and liquidated;

b) "available techniques" mean techniques with such degree of development, which makes it possible to use them in practice in a given branch of industry, taking into account economic and engineering conditions and the account of investment costs and benefits for the environment, which (techniques) a given businessman may acquire;

c) "the best technique" means the technique that is most effective in achieving an overall higher level of protection of the environment as a whole.

In the light of the above, a BAT installation prevents pollution by:

- using environmentally friendly raw materials;

- manufacturing environmentally friendly products (that are recyclable, have long lifetimes, etc.),

- effectively using its resources (water, energy, raw materials) and

- minimising its volumes of waste, recycling and re-using it, making its cleaning and storage solution the final solution (in case there is no other possibility).

From the environmental point of view, especially hazardous impacts may be caused by manufacturing processes being carried out, among other things, in the following plants [3]:

- food producing and processing plants - due to the use of ammonia w cold stores, flammable materials in distillery processes using e.g. formaldehyde, solvents, hexane in food processing, explosive rates of loose products, e.g. sugar or flour;

- natural resources excavating and processing plants - due to explosiveness of materials, contamination of such plants' surroundings, and waste arising while excavating crude oil, coal, metals and minerals, or gas;

- manufacturing industry plants - due to storage of fuels, using solvents and other hazardous chemical substances. This group comprises, among other things, glass foundries (that use heavy metals), brickyards (fuels), dye-houses (solvents, hydrocarbons), metal plants $\left(\mathrm{CO}, \mathrm{NO}_{\mathrm{X}}\right.$, solvents, $\mathrm{SO}_{2}$, cyanide compounds);

- $\quad$ energy producing and distributing plants - due to emissions of $\mathrm{SO}_{2}, \mathrm{NO}_{\mathrm{x}}$, dusts, generation of waste that contains heavy metals, storage and usage of chlorine used to treat cooling water, as well as possible radiological threats;

- $\quad$ waste storing and neutralising plants - a real hazard is posed by warehouses of flammable and toxic gases or liquids with explosive characteristics, as well as solids, which generate toxic substances in case of fire. Among other things, the above refers to fuel wholesalers, corn silos, plastic material warehouses. It is similarly dangerous to store waste in dumps, or tanks, from which, among other things, flammable methane is released.

Environmentally-friendly technologies are not merely perceived as single technologies. In fact, they are quite comprehensive systems that may cover: know-how, activities, procedures, goods, services, facilities, and even organisation and management techniques and standards [13]. Thus, technologies of this type use eco-innovative solutions related not only to technological innovations but also to new products and services, including transportation [5], and business practices that reduce adverse environmental impacts or make it possible to use resources in the optimum manner.

The basic objectives required from environmentally-friendly technologies are related to the development of innovative energy- and material-saving manufacturing technologies, which, in particular, make use of renewable resources [2]. Activities conducted must be compliant with the "3R" (Reduce - Reuse - Recycle) principle aimed at reducing the volume of industrial waste, including securing and recycling the waste that has already been generated, as well as recovery of materials contained in the waste as a result of manufacturing and consumption processes [12]. These activities fit within the concept of sustainable production and consumption [11], i.e. such production of goods and services, whereby processes and systems are used, which do not pollute the environment (or which reduce its pollution), which save energy and raw materials, are economically viable, safe, not hazardous to human health, and socially and creatively payable for all those who are involved in it.

\section{RESEARCH METHODOLOGY}

Within the frameworks of this study, statistical data was reviewed concerning capital expenditures incurred in the years 2010-2012 by companies from the industrial processing section towards environmental protection fixed assets (proenvironmental capital expenditures) from the point of view of spending directions structure on protection of the air (AP), water (WP), surface of the earth against waste (GSP), soil and underground and surface water (SP), protection against noise (PAN), as well as on other environmental protection activities and research and development works (OT), taking into account investment types, i.e. whether they were end-of-pipe investments (EPI) or integrated technology (IT) investments.

End-of-pipe investments are investments which do not interfere with the manufacturing process (production may be run without such investments), but which reduce or neutralise pollution being generated in the manufacturing process. In line with the methodology as recommended by European Union's EUROSTAT Statistical Office, amounts spent on this type of ventures are fully included into environmental protection expenditures.

On the other hand, integrated technologies comprise investments that lead to reduction in the volume of generated pollution by modifying technological processes, which results in production processes becoming cleaner and more environmentally-friendly.

Expenditures made towards fixed assets are amounts spent on purchases of land, buildings, premises, civil and water engineering structures, technical facilities and machines, means of transport, tools, instruments, moveable property and its 
equipment and other fixed assets, in order to achieve some protective effects or water management effects.

Data concerning amounts spent on environmental protection fixed assets and their material effects has been presented since 1999 in accordance with the Polish Statistical Classification of Environmental Protection Activities and Facilities [10]. This classification has been developed upon the basis of the ECE/UN Single European Standard Statistical Classification of Environmental Protection Activities and the European System for the Collection of Economic Information on the Environment (SERIEE) implemented by the European Union. This data is comparable with data as presented since 1996. Nine environmental protection areas have been distinguished between, such as: protection of the atmospheric air and climate, wastewater management and protection of water, waste management, soil protection and restoration of the usable value of the soil, protection of underground and surface water, reduction of noise and vibration levels, protection of biological diversity and landscape, protection against ionizing radiation, research and development works, and other environmental protection activities.

For the needs of this study, three coefficients were used based upon amounts of pro-environmental capital expenditures (amounts spent on environmental protection fixed assets) incurred in a given direction (or domain) and, respectively, upon the number of companies (coefficient $\mathrm{C} 1$ in thousand PLN per one company), upon average employment (coefficient $\mathrm{C} 2$ in PLN per one employee), and upon the gross value of fixed assets obtained from total investment activities (coefficient C3 in \%).

Data as gathered and published by the Polish Central Statistical Office (GUS) [9] was used to conduct this study. It covers businesses that employ more than 9 persons.

\section{RESEARCH RESULTS}

\subsection{Structural analysis of pro-environmental capital expenditures from the standpoint of investment directions and types}

Analysis of the structure of total pro-environmental capital expenditure directions - Figure 1 - suggests that in the analysed years 2010-2012 in the industrial processing sector in Poland, the highest average share pertained to the amounts that were spent on air protection (AP) $-63.83 \%$ and water protection (WP) $21.94 \%$, whereas in case of amounts spent on air protection (AP), a fall was observed in their share from $68.37 \%$ in 2010 to $60.25 \%$ in 2012 , and in case of water protection (WP), an increase was observed from $18.29 \%$ in 2010 to $24.08 \%$ in 2012.

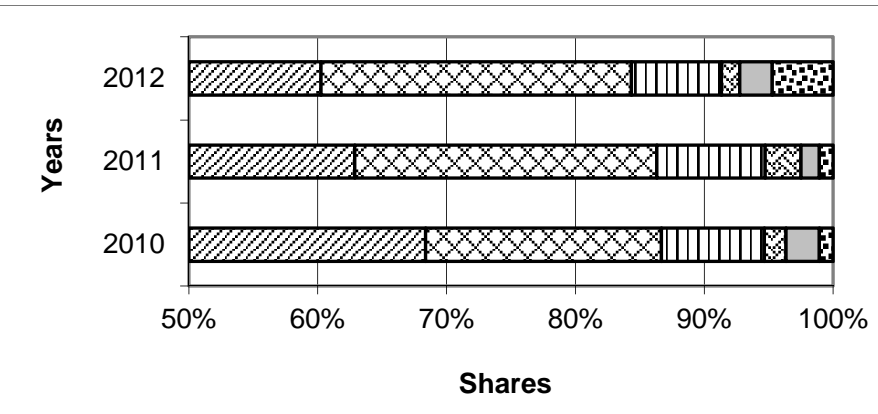

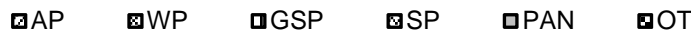

Figure 1. Structure of total pro-environmental capital expenditure directions in the industrial processing sector in the years 2010-2012.
Source: own elaboration on the basis of data from GUS.

At the same time, as a result of analysis of the structure of proenvironmental capital expenditure directions, depending upon investment types - Table 1, it was found that in the analysed years 2010-2012, end-of-pipe investments (EPI) pre-dominated with the average share of $73.3 \%$, and an increase was observed in the share of end-of-pipe investments (EPI) from $65.8 \%$ in 2010 up to $73.0 \%$ in 2012 , and a fall was observed in the share of integrated technology (IT) investments - from $34.2 \%$ in 2010 to $27.0 \%$ in 2012 .

Table 1. Structure of pro-environmental capital expenditure directions in the years 2010-2012, depending upon investment types (in \%).

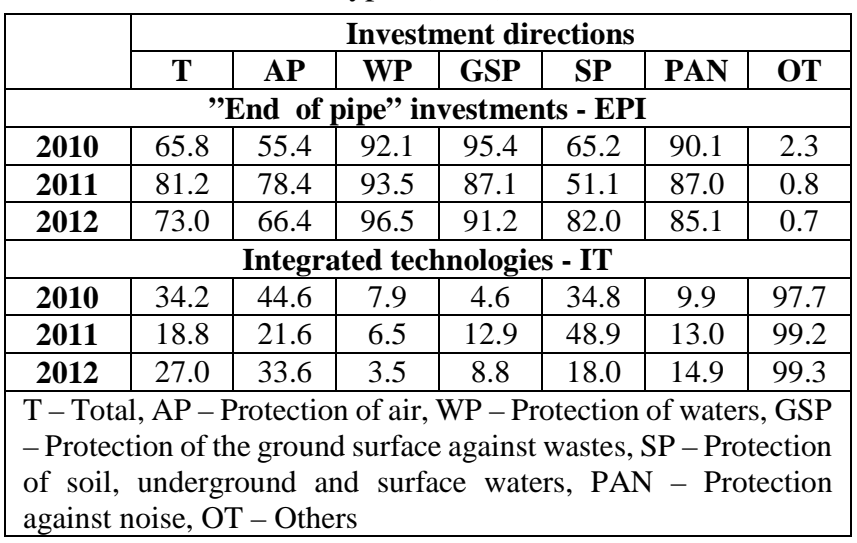

Source: own elaboration on the basis of data from GUS.

Furthermore, while comparing shares for the particular investment directions AP, WP, GSP, SP, PAN and OT between end-of-pipe investments (EPI) and integrated technology (IT) investments, it can be concluded that in case of the investment direction described as "other investments", which, effectively, covers amounts spent on research and development works, it pre-dominated for integrated technologies $-98.7 \%$ on the average in the analysed years.

Then, analysing the structure of directions pro-environmental expenditures in the form of end-of-pipe investments (EPI) Figure 2, it can also be noticed that in the years 2010-2012 in the industrial processing sector, expenditures oriented towards air protection (AP) dominated - $57.70 \%$ on the average, and towards water protection (WP) $-28.15 \%$ on the average, whereas a fall was observed for end-of-pipe air protection projects (AP) from $57.57 \%$ in 2010 to $54.83 \%$ in 2012, and an increase was observed for water protection projects (WP) - from $25.60 \%$ in 2010 up to $31.84 \%$ in 2012 .

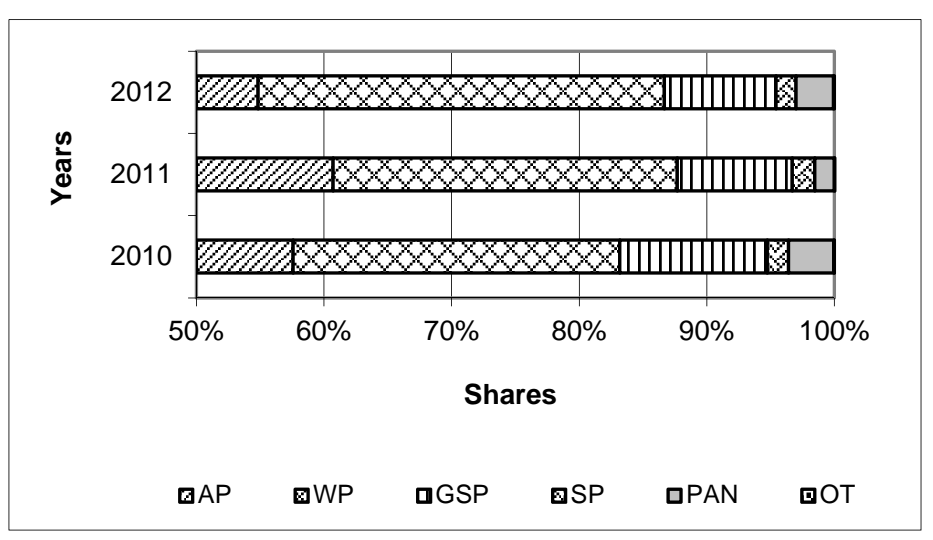

Figure 2. Structure of pro-environmental expenditure directions in the form of end-of-pipe investments in the industrial processing sector in the years 2010-2012.

Source: own elaboration on the basis of data from GUS. 
In the same way, analysis of the structure of pro-environmental expenditure directions in the form of integrated technology (IT) investments - Figure 3 - points to a fall in the share of expenditure made towards air protection projects (AP) in the industrial processing sector from $89.19 \%$ in 2010 to $74.93 \%$ in 2012 , and to a statistically significant increase in the share of expenditure made towards research and development works (OT) - from $3.05 \%$ in 2010 to $17.35 \%$ in 2012, with much higher average share of amounts spent on air protection projects (AP) $78.78 \%$ on the average.

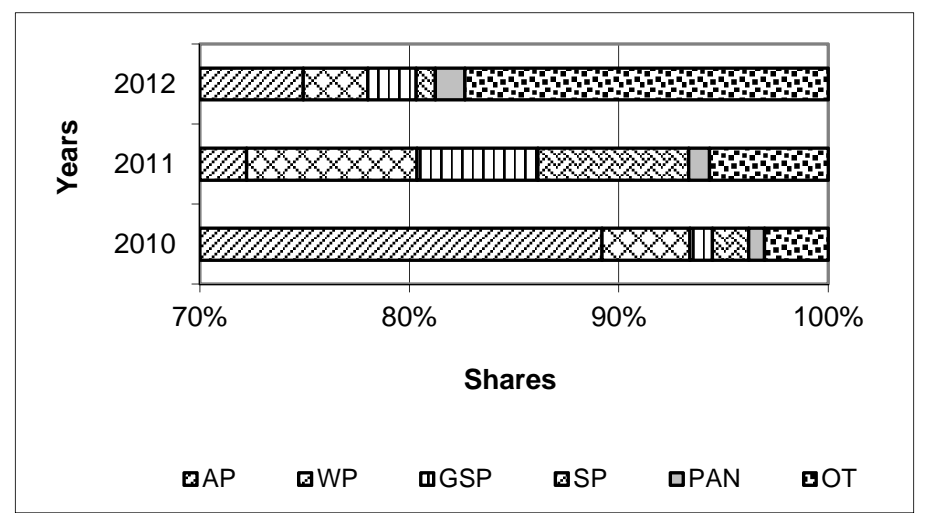

Figure 3. Structure of pro-environmental expenditure directions in the form of integrated technology investments in the industrial processing sector in the years 2010-2012.

Source: own elaboration on the basis of data from GUS.

\subsection{Coefficient analysis of pro-environmental} capital expenditures from the standpoint of investment directions and types

\subsubsection{Analysis involving the number of companies}

Analysis of the amount of pro-environmental capital expenditures per one company - Figure 4 - suggests that in the years 2010-2012, total expenditures (T) were 95.7 thousand PLN per one company on the average, whereas in case of endof-pipe investments (EPI), it was 70.6 thousand PLN on the average, and in case of integrated technology (IT) investments 25.1 thousand PLN per one company on the average.

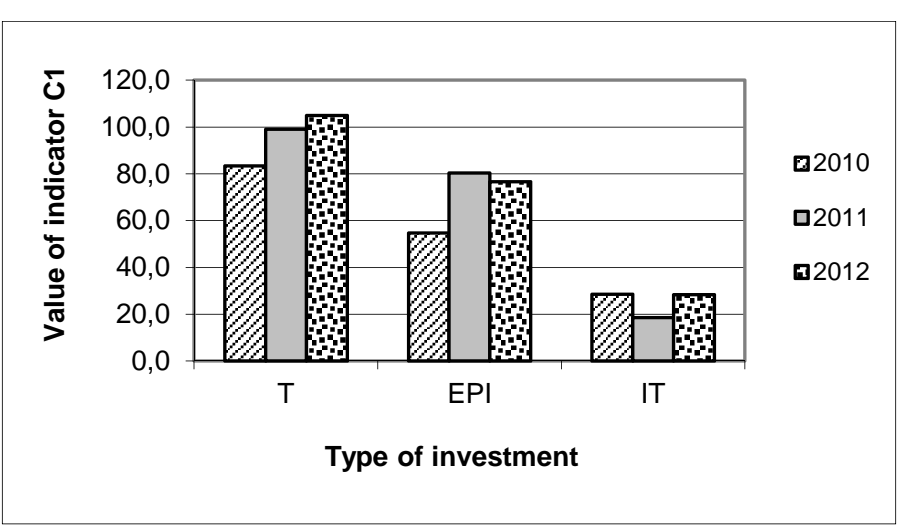

Figure 4. Amount of total pro-environmental capital expenditures per one company in the years 2010-2012 (in thousand PLN).

Source: own elaboration on the basis of data from GUS.

Furthermore, it should be noted that in the analysed years, there occurred an increase in total expenditures ( $\mathrm{T}$ ) from 83.3 thousand PLN in 2010 up to 104.9 thousand PLN in 2012, and an increase in amounts spent on end-of-pipe investments (EPI) from 54.8 up to 76.6 thousand PLN per one company.
At the same time, analysis of pro-environmental capital expenditure directions - Table 2 - suggests that in the years 2010-2012, in case of end-of-pipe investments (EPI), on the average, 40.8 thousand PLN was spent on air protection (AP), and 20.0 thousand PLN on water protection per one company, whereas in case of integrated technology (IT) investments, 20.0 thousand PLN was spent on air protection (AP), and 2.3 thousand PLN was spent on research and development works (OT) per one company.

Table 2. Pro-environmental capital expenditure directions in the years 2010-2012, depending upon investment types, based upon the $\mathrm{C} 1$ coefficient.

\begin{tabular}{|c|c|c|c|c|c|c|}
\hline \multirow[t]{2}{*}{ C1 } & \multicolumn{6}{|c|}{ Investment directions } \\
\hline & AP & WP & GSP & SP & PAN & OT \\
\hline \multicolumn{7}{|c|}{ “End of pipe" investments - EPI } \\
\hline 2010 & 31.6 & 14.0 & 6.3 & 0.9 & 1.9 & 0.0 \\
\hline 2011 & 48.8 & 21,7 & 7.2 & 1.4 & 1.2 & 0.0 \\
\hline 2012 & 42.0 & 24.4 & 6.7 & 1.2 & 2.3 & 0.0 \\
\hline \multicolumn{7}{|c|}{ Integrated technologies - IT } \\
\hline 2010 & 25.4 & 1.2 & 0.3 & 0.5 & 0.2 & 0.9 \\
\hline 2011 & 13.4 & 1.5 & 1.1 & 1.3 & 0.2 & 1.1 \\
\hline 2012 & 21.2 & 0.9 & 0.7 & 0.3 & 0.4 & 4.9 \\
\hline \multicolumn{7}{|c|}{$\begin{array}{l}\text { AP - Protection of air, WP - Protection of waters, GSP - } \\
\text { Protection of the ground surface against wastes, SP - Protection } \\
\text { of soil, underground and surface waters, PAN - Protection } \\
\text { against noise, OT - Others }\end{array}$} \\
\hline
\end{tabular}

Source: own elaboration on the basis of data from GUS.

\subsubsection{Analysis involving the size of employment}

Analysis of the amount of pro-environmental capital expenditures per one employee - Figure 5 - suggests that in the years 2010-2012, total expenditures (T) were 464 PLN per one employee on the average, whereas in case of end-of-pipe investments (EPI), it was 217 PLN on the average, and in case of integrated technology (IT) investments, it was 121 PLN on the average per one employee in the industrial processing sector.

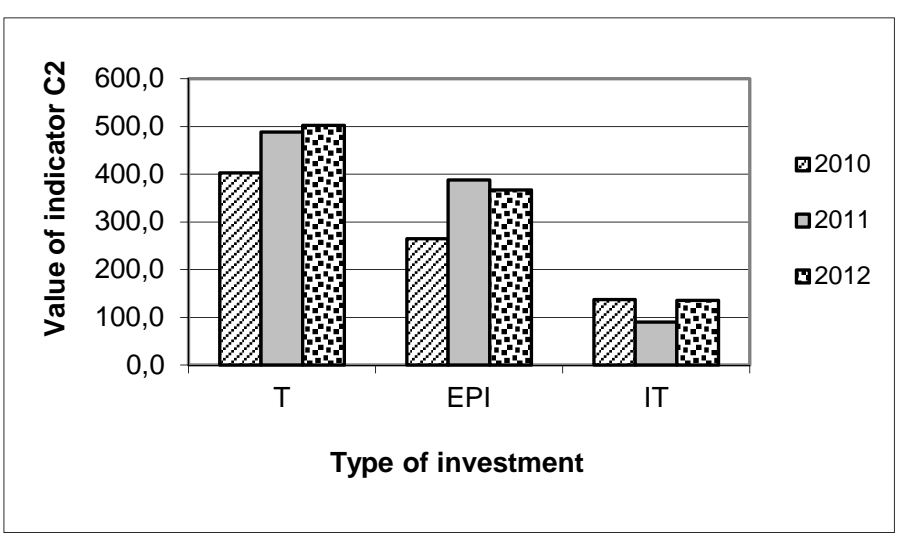

Figure 5. Amount of pro-environmental capital expenditures per one employee in the years 2010-2012 (in PLN).

Source: own elaboration on the basis of data from GUS.

Furthermore, an increase should be noted in total expenditures (T) from 402 PLN in 2010 up to 502 PLN in 2012, and an increase in amounts spent on end-of-pipe investments (EPI) from 265 to 367 PLN per one employee.

At the same time, analysis of pro-environmental capital expenditure directions - Table 3 - suggests that in the years 2010-2012, in case of end-of-pipe investments (EPI), 196 PLN on the average was spent on air protection (AP), and 96 PLN on the average was spent on water protection per one employee, whereas in case of integrated technology (IT) investments, 96 PLN was spent on air protection (AP) on the average, and 11 
PLN was spent on research and development works (OT) per one employee in the industrial processing sector.

Table 3. Pro-environmental capital expenditure directions in the years 2010-2012, depending upon investment types, based upon the $\mathrm{C} 2$ coefficient.

\begin{tabular}{|c|c|c|c|c|c|c|}
\hline \multirow{2}{*}{ C2 } & \multicolumn{7}{|c|}{ Investment directions } \\
\cline { 2 - 7 } & AP & WP & GSP & SP & PAN & OT \\
\hline \multicolumn{7}{|c|}{ "End of pipe" investments - EPI } \\
\hline $\mathbf{2 0 1 0}$ & 152.5 & 67.8 & 30.6 & 4.5 & 9.4 & 0.1 \\
\hline $\mathbf{2 0 1 1}$ & 235.3 & 104.6 & 34.9 & 6.8 & 6.0 & 0.0 \\
\hline $\mathbf{2 0 1 2}$ & 201.0 & 116.7 & 32.1 & 5.8 & 10.9 & 0.2 \\
\hline \multicolumn{7}{|c|}{ Integrated technologies - IT } \\
\hline $\mathbf{2 0 1 0}$ & 122.6 & 5.8 & 1.5 & 2.4 & 1.0 & 4.2 \\
\hline $\mathbf{2 0 1 1}$ & 64.8 & 7.3 & 5.2 & 6.5 & 0.9 & 5.1 \\
\hline $\mathbf{2 0 1 2}$ & 101.5 & 4.2 & 3.1 & 1.3 & 1.9 & 23.5 \\
\hline
\end{tabular}

AP - Protection of air, WP - Protection of waters, GSP Protection of the ground surface against wastes, SP - Protection of soil, underground and surface waters, PAN - Protection against noise, OT - Others

Source: own elaboration on the basis of data from GUS. It should be also noted that in case of end-of-pipe technology investments (EPI), for amounts spent on air protection (AP), an increase was observed from 152 PLN in 2010 up to 201 PLN in 2012, and for amounts spent on water protection (WP), an increase was observed from 68 PLN in 2010 up to 117 PLN in 2012, whereas in case of integrated technology (IT) investments, for amounts spent on air protection (AP), a fall was observed from 122 PLN in 2010 to 101 PLN in 2012, and an increase for amounts spent on research and development works (OT) - from 4 PLN in 2010 up to 23 PLN in 2012 per one employee within the manufacturing companies.

\subsubsection{Analysis involving the value of fixed assets}

Analysis of the share of total amounts spent on environmental protection fixed assets in the value of fixed assets obtained from investment activities - Figure 6 - suggests that, on the average, in the years 2010-2012, total amounts spent on environmental protection fixed assets constituted $1.75 \%$ of the total value of fixed assets obtained from investment activities, and this share increased within the analysed period from $1.70 \%$ in 2010 up to $1.92 \%$ in 2012 .

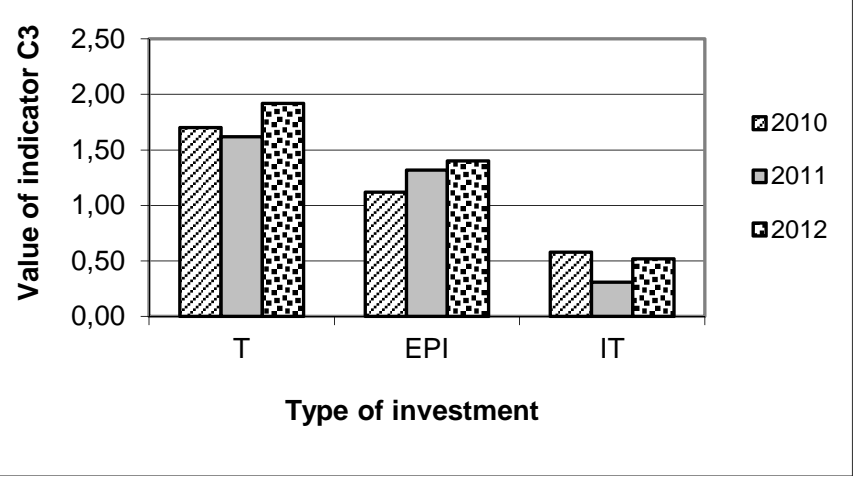

Figure 6. The share of total amounts spent on environmental protection fixed assets in the total value of fixed assets obtained from investment activities in the years 2010-2012 (in $\%)$.

Source: own elaboration on the basis of data from GUS.

Also, the share of amounts spent on environmental protection fixed assets classified as end-of-pipe investments (EPI) increased from $1.12 \%$ in 2010 up to $1.40 \%$ in 2012 . With the average value within the analysed period being $1.28 \%$. The average value for integrated projects was as low as $0.48 \%$.
At the same time, analysis of pro-environmental capital expenditure directions in the years 2010-2012, depending upon investment types - Table 4 - suggests that in case of end-of-pipe investments (EPI), amounts spent on air protection (AP) fixed assets constituted $0.74 \%$ on the average, and amounts spent on water protection constituted $0.37 \%$ of the total value of fixed assets obtained from investment activities.

Table 4. Pro-environmental capital expenditure directions in the years 2010-2012, depending upon investment types, based upon the $\mathrm{C} 3$ coefficient

\begin{tabular}{|c|c|c|c|c|c|c|}
\hline \multirow{2}{*}{$\mathbf{C 3}$} & \multicolumn{7}{|c|}{ Investment directions } \\
\cline { 2 - 7 } & AP & WP & GSP & SP & PAN & OT \\
\hline \multicolumn{7}{|c|}{ "End of pipe" investments - EPI } \\
\hline $\mathbf{2 0 1 0}$ & 0.64 & 0.29 & 0.13 & 0.02 & 0.04 & 0.00 \\
\hline $\mathbf{2 0 1 1}$ & 0.80 & 0.36 & 0.12 & 0.02 & 0.02 & 0.00 \\
\hline $\mathbf{2 0 1 2}$ & 0.77 & 0.45 & 0.12 & 0.02 & 0.04 & 0.00 \\
\hline \multicolumn{7}{|c|}{ Integrated technologies - IT } \\
\hline $\mathbf{2 0 1 0}$ & 0.52 & 0.02 & 0.01 & 0.01 & 0.00 & 0.02 \\
\hline $\mathbf{2 0 1 1}$ & 0.22 & 0.02 & 0.02 & 0.02 & 0.00 & 0.02 \\
\hline $\mathbf{2 0 1 2}$ & 0.39 & 0.02 & 0.01 & 0.00 & 0.01 & 0.09 \\
\hline $\begin{array}{l}\text { AP - Protection of air, WP - Protection of waters, GSP - } \\
\text { Protection of the ground surface against wastes, SP - Protection } \\
\text { of soil, underground and surface waters, PAN - Protection } \\
\text { against noise, OT - Others }\end{array}$ \\
\hline
\end{tabular}

Source: own elaboration on the basis of data from GUS.

Furthermore, it should be noted that for end-of-pipe technology investments (EPI), in case of air protection (AP) fixed assets, an increase was observed in their share from $0.64 \%$ in 2010 up to $0.77 \%$ in 2012, and in case of water protection (WP) fixed assets, an increase was observed from $0.29 \%$ in 2010 up to $0.45 \%$ in 2012, whereas for integrated technology (IT) investments, in case of air protection (AP) fixed assets, a fall was observed in their share from $0.52 \%$ in 2010 to $0.39 \%$ in 2012 , and in case of amounts spent on research and development works (OT), an increase was observed in their share from $0.02 \%$ in 2010 up to $0.09 \%$ in 2012 .

\section{SUMMARY}

Whereas the basic objectives of each company include profit and growth in goodwill, activities undertaken for favour of natural environment as part of the sustainable development concept are considered by most entrepreneurs to be a significant organisational, technical and financial nuisance in running their businesses, especially for companies from the small- and medium-size businesses sector [4]. Shaping the company's image as the one that takes sustainable development rules into account in its strategy is helpful in achieving a strong competitive position both at domestic and the foreign markets, especially western ones, where such standards are already widespread, which, in a longer perspective, is bound to secure some measurable benefits to companies [8].

This article analyses practical implementation of the sustainable development concept in manufacturing companies in Poland in the years 2010-2012 by analysing directions of spending on environmental protection fixed assets, depending upon investment types: end-of-pipe investments and integrated technology investments.

The analyses we have conducted made it possible for us above all to find out that in the analysed years 2010-2012, in the industrial processing sector in Poland, the highest average share of amounts spent on environmental protection fixed assets was associated with air and water protection, whereas in case of amounts spent on ways and means of air protection, a fall was observed in their share, and an increase in case of water 
protection. Furthermore, we also discovered that within the analysed period, end-of-pipe investments pre-dominated within the structure, whereas an increase was observed in the share endof-pipe investments, and a fall in the share of integrated technology investments. On the other hand, integrated technologies were more frequently related to research and development works within the area of environmental protection than end-of-pipe investments.

At the same time, we found that in the analysed years, total amounts spent on environmental protection fixed assets were, on the average, 95.7 thousand PLN per one company and 464 PLN per one employee, and that they constituted $1.75 \%$ of the total value of fixed assets obtained from investment activities, showing a growing tendency in each of the above-mentioned cases. In the event of end-of-pipe investments, amounts spent on environmental protection fixed assets were, on the average, 70.6 thousand PLN per one company and 217 PLN per one employee, and they constituted $1.28 \%$ of the total value of fixed assets obtained from investment activities, also exhibiting a growing tendency in each of these cases.

On the other hand, amounts spent on integrated technology investments were, on the average, 25.1 thousand PLN per one company and 121 PLN per one employee, and constituted $0.48 \%$ of the value of fixed assets obtained from investment activities, also exhibiting a growing tendency in each of these cases.

We also found that in case of end-of-pipe investments, expenditures oriented towards protection of the air and water predominated, and we observed a fall in the analysed years in the amounts spent on air protection projects, and an increase in the amounts spent on water protection projects. Also in case of integrated technology investments, we observed a fall in the share of amounts spent on air protection projects, and a statistically significant increase in the share of amounts spent on research and development works.

As is commonly believed by specialists, most pro-ecological solutions require no sophisticated high-tech type manufacturing technologies at all. Rather than that, they are classified as middle-tech type technologies. On the whole, it is important to make them more popular by making some selected proecological technologies available to entrepreneur groups as part of some determined form of allowable public assistance, as well as to develop some information tools designed for a broad circle of addresses who are interested in the economic aspects of environmental protection activities, for instance in the form of a database of domestic pro-ecological technologies [12].

Functioning within determined economic, social, and natural environment, companies exert a direct impact upon it, which is frequently negative, thus provoking conflicts among various stakeholder groups. Therefore, they should bear responsibility for their activities, and take an active part in solving environmental and social problems.

\section{REFERENCES}

1. Adamczyk, J., Koncepcja zrównoważonego rozwoju w zarzadzaniu przedsiębiorstwem, Wyd. Akademii Ekonomicznej w Krakowie, Kraków, pp. 183, (2001).

2. Bajdor, P., Comparison between Sustainable Development Concept and Green Logistics - the Literature Review, Polish Journal of Management Studies, Vol.5, pp. 225-233, (2012).

3. Borysiewicz, M., Kacprzyk, W., Żurek, J., Zintegrowane oceny ryzyka $i$ zarządzania zagrożeniami $w$ obszarach przemystowych, Wyd. CIOP, Warszawa, (2001).

4. Grabara, J., Bajdor, P., Implementation the Solution Compatible with Sustainable Development Conception and Its Impact of SME Enterprises Economic Condition, [in:] Economic Policy in the European Union Member Countries, $10^{\text {th }}$ International Scientific Conference, September 19-21, Vendryne, Czech Republic, (2012).

5. Kot, S., Ślusarczyk, B., Sustainable Development Analysis in Transport Process, Studia Ekonomiczne Zeszyty Naukowe Uniwersytetu Ekonomicznego w Katowicach, Nr 121, pp. 141-146, (2012).

6. Kryk, B., Koncepcja społecznej odpowiedzialności przedsiębiorstwa za środowisko przyrodnicze, [w:] Teoretyczne aspekty gospodarowania, red. D. Kopycińska, Wyd. Uniwersytet Szczeciński, Szczecin, pp. 200, (2005).

7. Malik, K., Wybrane aspekty zarządzania ekologicznego, Zarzadzanie Produkcja, Nr 1-2, (1999).

8. Nowak, S., Franczak, A., Zarządzanie konkurencyjnością a CSR i zrównoważony rozwój przedsiębiorstwa, Logistyka, Nr 6, pp. 190-196, (2012).

9. Roczniki branżowe. Roczniki statystyczne przemystu 20102012, GUS, Warszawa, (2011-2013).

10. Rozporządzenie Rady Ministrów z dnia 2 marca 1999 r. Polska Klasyfikacja Statystyczna Dotyczaca Działalności $i$ Urządzeń Związanych z Ochrona Środowiska (Dz. U. Nr 25, poz. 218)

11. Sustainable consumption and production in South East Europe, Eastern Europe, Caucasus and Central Asia, European Environmental Agency Report 3/2007, Copenhagen, (2007).

12. Tabor, J., Pro-Ecology Technologies in the Development of Small and Medium-Sized Companies, [in:] Technological and Socio-Economical Aspects of Environmental Protection in Industry, Monograph. Ed. Wioletta M. Bajdur, Wyd. WZPCzest. Częstochowa, pp. 153-168, (2010).

13. Urbaniak, M., Zastosowanie norm i kierunki doskonalenia systemów zarządzania środowiskowego i bhp, Automatyka, Nr 10, pp. 46-52, (2007).

14. Ustawa $\mathrm{z}$ dnia 27 kwietnia 2001 r. Prawo ochrony środowiska, (tj. Dz. U. Nr 25 z 2008 r. poz. 150 ze zmianami). 